\title{
CONSERVING GEO-DIVERSITY: THE IMPORTANCE OF VALUING THE HERITAGE ELEMENTS AT LANGKAWI GEOPARK
}

\author{
N.S.M. FAUZI ${ }^{1} \&$ A. MISNI ${ }^{2}$ \\ ${ }^{1}$ Faculty of Architecture, Planning and Surveying, Universiti Teknologi MARA (UiTM), \\ Shah Alam, Selangor, Malaysia. \\ ${ }^{2}$ Faculty of Architecture, Planning and Surveying, Universiti Teknologi MARA (UiTM), \\ Puncak Alam, Selangor, Malaysia.
}

\begin{abstract}
Geo-diversity is actually one of the priceless assets of national historical elements. Historical elements include nature, culture, monument, archaeological sites and others. The term 'Geo-diversity' encapsulates the richness and the variety of the earth's elements including materials, forms and processes, which naturally constitute and shape the earth and its historical background. Relevant materials such as minerals, rocks, fossils and water as well as other natural processes that include erosions and landslides are intimately linked with biodiversity. However, as the urbanization process has grown further, rapid developmental growth has resulted in high risk towards diversity, including geo-diversity itself. For instance, an increasing demand for new development area, modern and fascinating facilities and other types of development have resulted in the overuse of both area and all those elements of natural resources that are less sustainable. Hence, this over-use will become a major concern that will eventually have a potential negative impact or pose a problem to the environment, and to become worse, it will affect the conservation of nature and lastly will contribute to loss of geo-diversity. Thus, conserving geo-diversity has become a part of the core business of nature conservation. The effort and initiatives for protection and preservation, formulation of a management plan as well as improvement of public understanding and appreciation towards flora, fauna, geological and geomorphological features are important to address the problems. Therefore, for this related field of study, SWOT analysis will be carried out for evaluating the importance of geo-diversity as heritage elements of Langkawi Geopark. This paper aims to discuss and describe the current condition, importance and the existing geo-diversity elements of the Langkawi Geopark. The significance of this research is to evaluate the importance of geo-diversity around Langkawi Geopark and the Geopark's contribution towards nature conservation while maintaining its historical value.
\end{abstract}

Keywords: geo-diversity, geopark, heritage, preservation.

\section{INTRODUCTION}

Nowadays, heritage has begun to have a significant impact on the tourism sector'. Heritage sites were realized as one of the most attractive destinations for tourists. Therefore, the ecotourism sector has become popular in recent development. According to Eder and Patzak [1], more and more countries have started to develop schemes for recognizing important geological and geomorphological sites or landscapes within their national boundaries. The ecotourism sector in Malaysia has the potential due to its natural attractions and unique geographical landscape. In addition, according to Sapari et al. [2], Malaysia is one of the 12 mega-biologically diverse countries in the world with large numbers of flora and fauna. Ecotourism in Malaysia has become one of the growing industries and is an important area for investment for the growth of the economy [3]. The Malaysian government has invested an enormous sum of money to develop the ecotourism sectors, and one of the spots is around the Langkawi Geopark.

The Geopark concept has been introduced all around the world. However, it was not easy to gain the official establishment of Geopark status by the United Nation of Educational, 


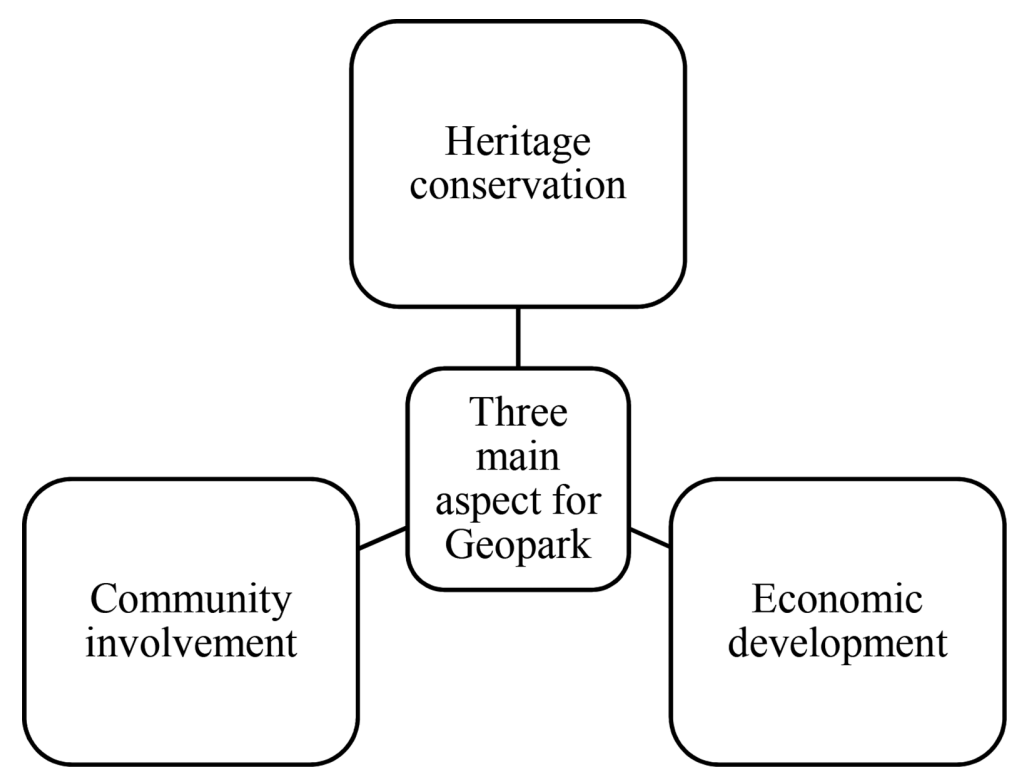

Figure 1: Three main aspects for the Geopark concept. (Modified from Fauzi and Misni [6]).

Sciences, and Cultural Organization (UNESCO). Any country that wanted to nominate any of its sites as a global Geopark member and gain Geopark status needs to fulfil the criteria set by UNESCO. According to LADA [4], the prefix 'geo' is taken from the Greek word which refers to the earth, while geology is the study of rock that relates to its history, formation, composition, structure, and also how the landscape has formed from the process of Earth's evolution from over millions of years ago.

Therefore, Geoparks means those areas or sites that serve an abundance of natural beauty, ecological harmony, and various archeological, geological and amazing cultural significance. Meanwhile, as mentioned by ProGEO [5], 'Geopark' could be defined as an informal (non-statutory) term to describe the complexes of geo-sites, or even small geo-sites, that are promoted for tourism purposes. In general, according to Fauzi and Misni [6], the Geopark concept will consider three main aspects: heritage conservation, economic development, and community involvement (Fig. 1). The Geopark concept has been introduced to sustain the heritage value while promoting ecotourism development. Community involvement, education and also socio-economic factors have been focused upon for developing the Geopark concept in order to obtain a sustainable approach. Therefore, in this paper, the strength, weakness, opportunities and threats (SWOT) analysis will be used for valuating the heritage elements around Langkawi Geopark [7].

\section{AREA OF STUDY}

Langkawi Geopark is located in the far northwestern corner of peninsular Malaysia. Situated in the northern State of Kedah, it is unique in the sense that it is formed of 99 islands that together make up the legendary Langkawi Archipelago [8]. The island was accorded Geopark status on June 1, 2007 and it was given the status because it fulfiled three key criteria set by UNESCO [4]. According to LADA [4], the criteria included having an extensive mangrove 


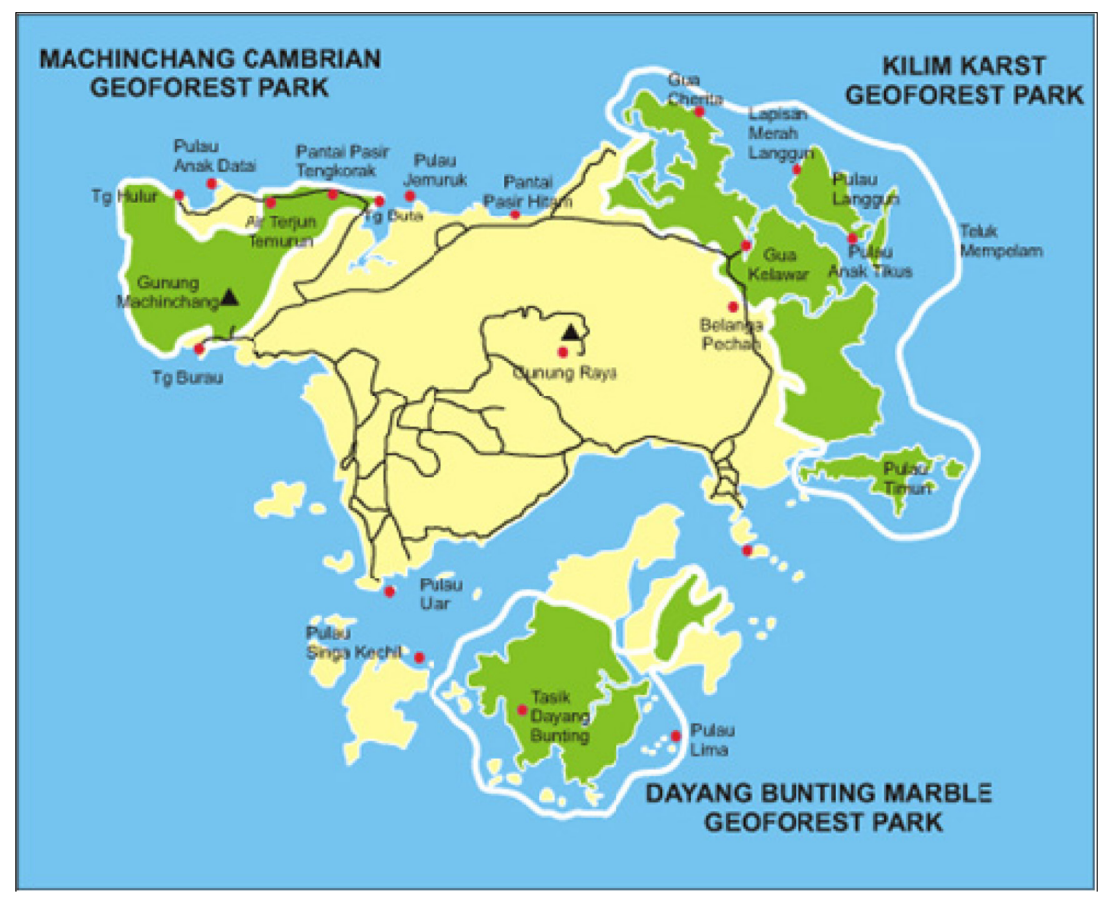

Figure 2: Map of Langkawi Geopark that show the location of three Geoforest Parks on Langkawi Island [4].

park, natural resources such as beaches and islands, as well as a multi-racial culture. Amazingly, Langkawi Geopark offers a valuable experience of exploring the meaning of 'integrating nature and human development'.

Langkawi Geopark consists of three areas (Figure 2) known as Machinchang Cambrian Geoforest Park, Kilim Karst Geoforest Park and Dayang Bunting Marble Geoforest Park. Each of the areas has its own special characteristic and uniqueness. Each of the areas contributes to the richness of the natural beauty of Langkawi and all the development planning has successfully attracted visitors from all around the world. Every year, there is a huge increase in the number of visitors coming to Langkawi. However, this paper will focus on the area of Kilim Karst Geoforest Park (KKGP), Langkawi, and all the elements around the area. KKGP is located in the far northwestern corner of peninsular Malaysia, $6^{\circ} \mathrm{N}$ Latitude and $99^{\circ}$ East Longitude, with elevation ranging between 15 and 200m [9].

KKGP, Langkawi, was under the responsibility of the Langkawi Development Authority (LADA).

According to LADA and Kumpulan Governans Pemuliharaan Warisan dan Pendidikan Universiti Kebangsaan Malaysia (UKM) [8], Langkawi Development Authority (LADA) was widely known as the main trusted body responsible for developing Langkawi Geopark and has been appointed as a coordinator of Langkawi Geopark by the Government of Kedah in May 2006. In 2007, LADA also received a funding from the Ministry of Finance in order to prepare the development planning for the Geopark project [10]. 


\section{ELEMENTS FOUND AT KILIM KARST GEOFOREST PARK, LANGKAWI}

KKGP, Langkawi, has been widely known because of its natural beauty which is rich in flora, fauna and beautiful landscape and there are also many tourism activities that have been provided to the local community as well as to tourists. Each year, the area around KKGP is improved and regularly developed in order to meet the needs and demands of the tourism sector. As one of a successful ecotourism destination in Malaysia, tourism in KKGP has become one of the growing industries and important investments contributing to the growth of the economy. Thus, according to Sapari et al. [2] the Malaysian government has invested a huge sum of money in developing the ecotourism sector and one such spot is the KKGP.

As an ecotourism destination, KKGP has welcomed numerous tourists from all over the world. Thus, in order to serve the best and high-quality services, KKGP has provided many infrastructures and amazing kind of activities. There are various elements provided around KKGP (Table 1). For example, there are man-made elements that have been developed and provided around the KKGP area to give comfort to their visitors while natural elements give the visitors a priceless view and memorable experiences.

KKGP, Langkawi, is surrounded by mangroves and the Kilim river. Therefore, the elements have made it special and interesting because the tourist needs to have a boat tour experience in order to discover the whole area of KKGP. The boat tour has been offered by two kinds of services. Generally, it is offered by the main management of Kilim (managed by the local community) and the other tour service is provided by tourism companies (agents). Both boat tour services serve different rates for their services. The tourists can freely choose their own boat services. Based on the rates, there are different kinds of tour services, activities and also experiences.

\section{SWOT ANALYSIS}

There are many interesting elements and experiences that could be explored around KKGP, Langkawi. Based on the current observation, KKGP has been well developed and is widely appreciated especially by nature lovers. However, sensitive areas and famous ecotourism destinations that have historical significance, such as KKGP, will usually face many risks and challenges towards sustainable development and need to be protected and well maintained. Thus, this paper will discuss the strength, weakness, opportunity and also threats that exist

Table 1: Classification of elements around Kilim Karst Geoforest Park, Langkawi.

\begin{tabular}{rll}
\hline No. & Natural elements & Man-made \\
\hline 1. & Mangrove sanctuary & Jetty \\
2. & Bat cave & Parking area \\
3. & Andaman Sea & Fish Farm \\
4. & Crocodile cave & Floating Restaurant \\
5. & Langsir cave & Boat/Cruise \\
6. & Anak Tikus Island (Fossil Island) & Toilet \\
7. & Kilim's Karst & Gazebo \\
8. & Mangrove Swamp & Management office \\
9. & Isolated island & Sanctuary Entrance \\
10. & Fossils & Timber decking \\
\hline
\end{tabular}


around KKGP. As an amazing historical area, KKGP has been surrounded by various natural treasures and is worth to be valued honorably.

\subsection{Strength}

There are many interesting elements that could be found around KKGP (Figure 3). Based on the historical aspect, the famous factor for KKGP is its geological elements. Around KKGP, there are various types of natural elements that could be found and one of the most interesting elements is the formation of the karst around the area.

The karst formation was believed to have existed from a long time ago. By renting a boat, the visitors can get the experience of exploring the area of KKGP which is surrounded by

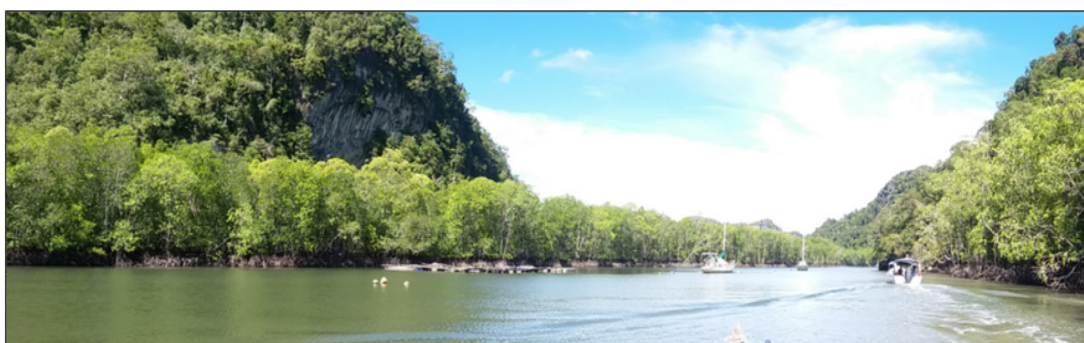

(i)

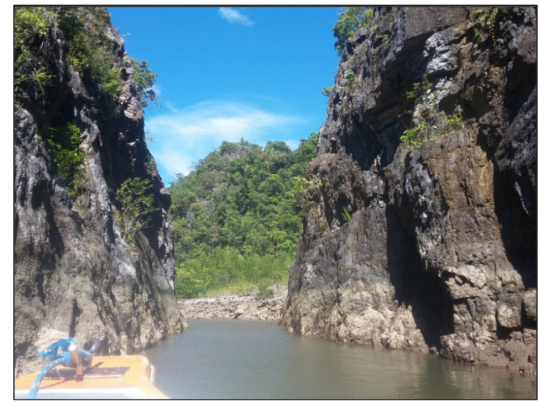

(ii)

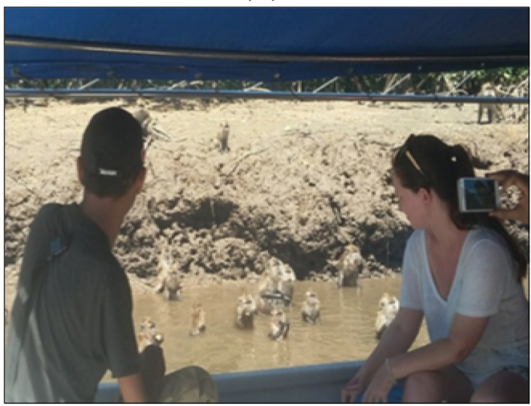

(iv)

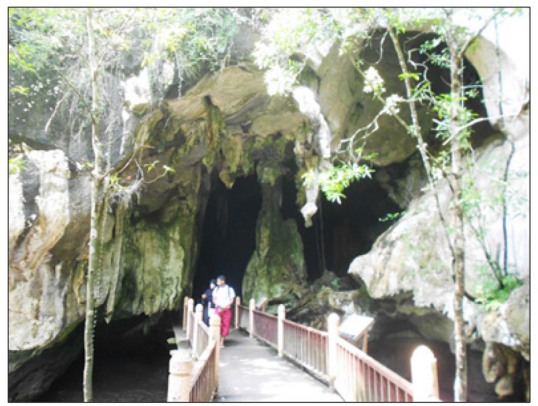

(iii)

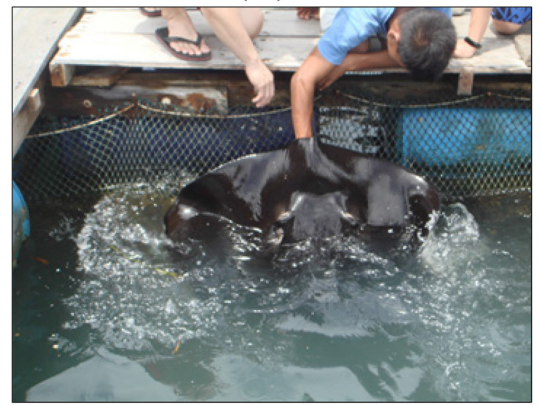

(v)

Figure 3: (i) Coastal mangrove swamp scenery, (ii) Karst formation (iii) Bat cave tour, (iv) Monkey feeding and (v) Fish feeding are the few interesting elements and activities during the boat tour. 
mangrove, various types of karst formation, and other flora and fauna. Besides, KKGP also serves the tourist with various types of interesting and memorable activities. Other than the boat tour, a tourist can experience the feeling of walking through the cave, feeding wild monkeys and eagles, exploring the mangrove swamp, fish farm and also having treats on the floating restaurants. However, this kind of experiences will depend on the boat tour packages chosen by the tourist.

KKGP, Langkawi, is so amazing with the presence of these historical and natural elements. All the experience and journey of the tourists along the KKGP will surely improve their awareness towards nature and appreciate all of the world's treasures. Thus, this will actually achieve the Geopark concept and objectives of preserving the historical elements while promoting tourism and improving the education aspect.

\subsection{Weakness}

As a famous ecotourism destination, KKGP has welcomed more and more tourists every year. The presence of the magnificent historic and natural elements, activities and views around KKGP has made it an interesting and must-visit destination for all. However, because of increasing tourists , KKGP has faced a lot of demand by the tourism sector. More and more new developments and infrastructure need to be installed around KKGP to give comfort as well as support visitor capacity.

Nevertheless, as a natural and sensitive area, KKGP should actually be strictly well protected from tourism factors. It is because, excessive exposure towards uncontrolled development and visitor capacity will give a big impact to the surrounding area. KKGP will face a risk of damaging the historical elements or even a loss of the natural elements as it becomes worse. Based on the observation, there are a few explanations and proofs (Fig. 5) of the weaknesses found around the KKGP. The following aspects are a few factors that show the weaknesses found around KKGP:

i. Lack of management control.

Each year KKGP has an issue from a sustainable development perspective. New development is needed in order to support visitor capacity. Unfortunately, due to sensitive sites around KKGP, the more natural damages issue has occurred (Figure 4). For example, according to Augustin [11], Ecotourism and Conservation Society Malaysia (EcoMy) president, Irshad Mobarak and other environmental NGOs are shocked over an issue regarding the KKGP mangrove area that has been destroyed for about four months between 2015 and 2016. As per the report, the sensitive area should not have been developed at all.

ii. An excessive number of visitors.

An excessive number of visitors to KKGP at one time have a big impact on KKGP. The sensitive area should be well protected from all kinds of possible risks. Thus, an excessive number of visitors will actually increase the number of boat tour services around KKGP. The uncontrolled boat services will actually affect the mangrove and karst area, wherein the boat waves could result in major damages and erosion to both of the elements.

iii. The uncontrolled number and speed limit of boat services.

The boat services are a major risk to the KKGP area. The uncontrolled number of boats, types of boats and also the speed limit of the boats have a negative effect on the surrounding area. For example, Idris [12] has reported that the mangrove area around KKGP is 


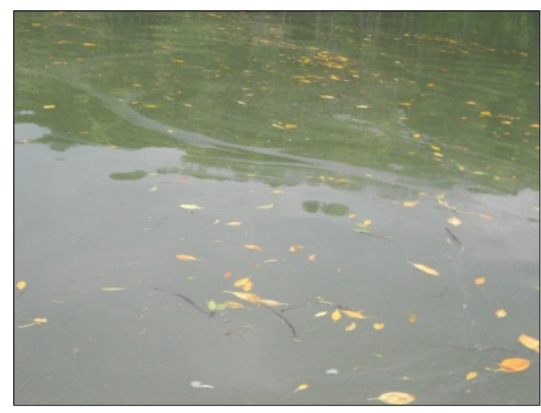

(i)

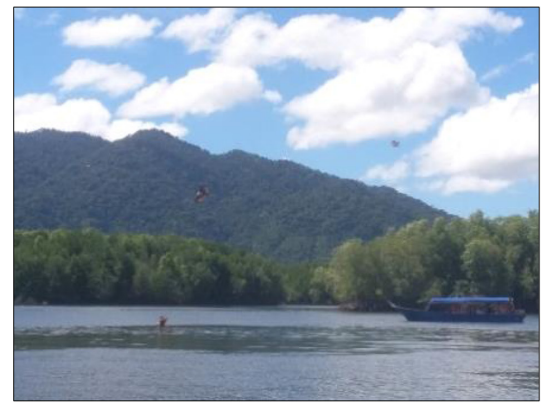

(iii)

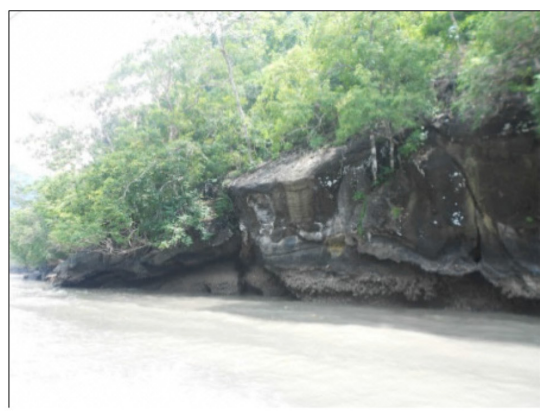

(ii)

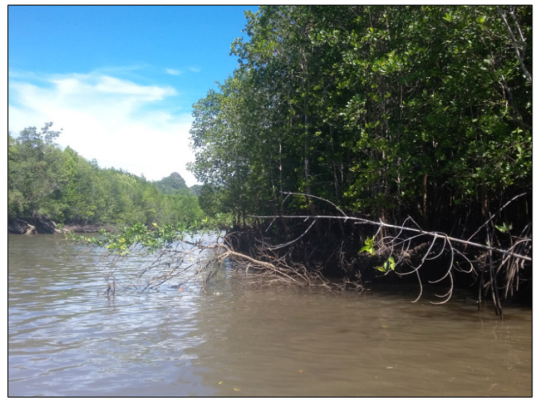

(iv)

Figure 4: (i) Water pollution as a result of chicken fat by eagle feeding activities, (ii) Karst erosion, (iii) Eagle feeding activities has resulted in less survival skills of wild eagles and (iv) Damages of mangrove tree from riverbank erosion were examples of the weaknesses found around KKGP as a result of the uncontrolled ecotourism sector.

being seriously threatened by boat tourist activities. In addition, according to the report from NAHRIM and NRE [13], the research has proven that the erosion of the riverbank area was affected by the impacts from the operating boats and it would worsen each year by the combination of natural conditions and the impacts of the wave generated by the boats.

iv. Lack of regular monitor and tour guide.

The natural area and historical elements are sensitive aspects that need to be focused and regularly monitored. Currently, KKGP was exposed to ecotourism activities. KKGP should be protected and well monitored by experts and tour guides. However, the current observation of the surroundings shows that KKGP was lacking in those aspects.

\subsection{Opportunity}

KKGP, Langkawi, has an amazing value towards Malaysian history and also its natural heritage assets. There are a lot of advantages and significance in developing and conserving the area. As a natural heritage site, KKGP has bright chances to become one of the famous living museums (Figure 5). Rather than having an enormous number of natural heritage assets, 


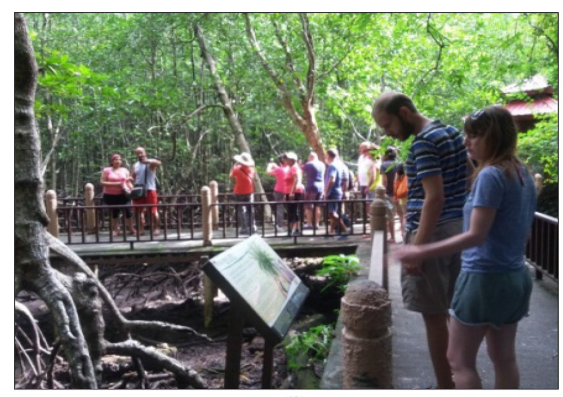

(i)

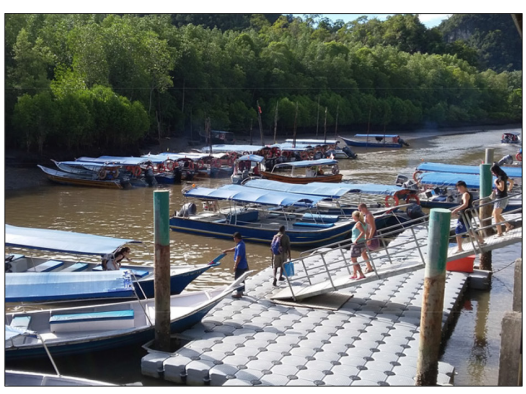

(ii)

Figure 5: (i) Tourists will be educated through the KKGP enjoyable journey and (ii) More job opportunities for local communities as the number of tourists increased show that KKGP has various opportunities to be one of the successful and valuable ecotourism destinations.

KKGP serves a million dollars' worth of enjoyable and memorable experience. Since KKGP is rich in natural heritage assets, all the elements in KKGP could provide an exciting non-formal educational journey. Towards this, the local community and tourists will get a chance to be educated towards the earth science related to geological and biological aspects while being introduced to the awareness of conserving and preserving the national heritage. The visitor could be introduced to the new experience of an educational programm which contributesto an exciting and enjoyable journey.

In addition, the introduction of ecotourism in KKGP has given a big chance to the local community for improving their socioeconomic development. The designation of KKGP as one of the Langkawi Geopark areas has offered lots of job opportunities for the local community. Thus, rather than preventing poverty around KKGP, the local community can improve their business and social activities while promoting the beauty of Langkawi. Plus, the increasing visitors to KKGP, will automatically increase the number of visitors to the other areas of Langkawi. Hence, it will also help to contribute to the economic growth of entire Langkawi by opening up more and various business sector opportunities.

Apart from that, the existence of KKGP as an ecotourism destination has improved the education level and knowledge of the local community and visitors towards the awareness and importance of valuing the heritage elements. The Geopark programs, information center and workshop helps in educating people about the importance of conserving and preserving the national heritage. Thus, this will help in realizing the sustainable development planning around KKGP and the other Langkawi Geopark areas. As a result, it will contribute to the protection of all the heritage assets around KKGP. All of the heritage assets will be treated wisely and be well protected in order to maintain their originality and value.

\subsection{Threats}

As a famous ecotourism destination, the biggest threats faced by KKGP were the conservation and sustainable development aspects. It is because, the major constraint in conserving KKGP was because it was one of the Langkawi Geopark areas. Langkawi Geopark was the first and only one Geopark in Malaysia. Therefore, there is a lack of information and models 
that could serve as inspiration for managing and developing KKGP in a specific and best way. Currently, there are no specific guidelines provided for this specific and sensitive area.

Langkawi Geopark consists of three different areas that have different characteristic and elements. Thus, each area should have its own guidelines on the management and conservation specifications in order to maintain and protect the geological and heritage value. Although Global Geopark Network (GGN) by the United Nations of Educational, Scientific and Cultural Organizaton (UNESCO) has set up standard criteria and guidelines, each Geopark around the world has its own characteristics and assets. Thus, it should be managed specifically and systematically due to the needs of the element. Therefore, it is quite challenging for KKGP to have specific guidelines because Langkawi Geopark is divided into three different characteristic and areas.

Besides, as a new Geopark area, the actual current constraint that lead to the biggest threats for KKGP is the intervention from a different management body that has the same right towards Langkawi Geopark area. With lack of management planning, there is an issue towards the structure of management bodies and the stakeholders. Hence, the contribution and yet the interference from the Langkawi Development Authority (LADA), NonGovernmental Organization (NGO), local community, Forestry Department and others could make it more complicated to sustain the heritage assets at KKGP. This is because, without a proper management body, it is difficult to obtain a standard management planning, experts' advise as well as a specific Geopark conservation team. Therefore, KKGP will actually never be able to be managed wisely as long as there are no strict regulations and a dedicated management team.

\section{DISCUSSION}

The ecotourism industry has evolved and brought various benefits towards the development concept of the country. Various advantages from different sectors, including socioeconomic, education and tourism and also historical elements have emerged and made an amazing impact on both the community and the country. However, ecotourism sector could also result in a negative impact towards any specific area, especially the area that is related to natural and sensitive sites. Thus, in order to maintain the originality and protect the heritage value, nature and sensitive sites such as KKGP should have been analyzed and focused properly upon for obtaining the most sustainable and systematic ways to develop the area.

Based on the SWOT Analysis results, the management and conservation aspect of KKGP should really take into account all the major concerns. KKGP, Langkawi, has an amazing number of attractions such as beautiful karst landscape scenery, mangrove swamps and an abundance of flora and fauna species. Each of these elements has a big influence on the visitors and provides strength towards enjoying their journey around KKGP. Thus, all of the elements should be conserved and well protected with proper guidelines. Besides, KKGP is known as for its natural richness of flora and fauna. Even if the ecotourism sector has evolved, development planning around KKGP area should maintain the originality and value of the natural and geological sites. Based on the analysis, there are a few weaknesses around KKGP regarding the management, maintenance, services and visitor capacity aspect. As an ecotourism destination, visitor capacity of KKGP should be well monitored and the area should be well protected in order to maintain its historical and natural value. Both of these aspects contribue to the growth and are key towards the success of KKGP as ecotourist destination.

KKGP, Langkawi, has a high potential and opportunity to become one of the most famous living museums that introduced nature and historical elements while serving an enjoyable 
journey. This opportunity has led KKGP to promote the knowledge of earth science and non-formal education that helps in improving community awareness towards protecting national heritage and natural elements. Thus, by conducting this analysis, all the data information on the constraint and threats that face KKGP could help in preparing suitable measures in addressing any development issues as well as promoting the importance of valuing the heritage assets around Langkawi Geopark.

\section{CONCLUSION}

In conclusion, Langkawi Geopark has really made Malaysia one of the famous worldwide ecotourism destinations. As the Langkawi Geopark has been gazetted, natural and historical elements around the area are hoped to be fully protected. Research and further studies in heritage elements from a conservation aspect are recommended in order to prepare more strategic planning, inspired information and idea towards maintaining the glory of KKGP and other areas of Langkawi Geopark. New development planning and the idea should give more respect towards the heritage elements and natural areas. Natural area and heritage elements are the most valuable assets and record the proof towards the establishment of the country.

\section{REFERENCES}

[1] Eder, F.W. \& Patzak, M., Geoparks - geological attractions: a tool for public education, recreation and sustainable economic development. Episodes-Newsmagazine of the International Union of Geological Sciences, 27(3), pp. 162-164, 2004.

[2] Sapari, M.S., Shuib, A., Ramachandran, S. \& Afandi, S.H.M. Visitors' satisfaction towards servise and facilities in Kilim Karst Geoforest Park, Langkawi. Aplied Economics and Business, 1(4), pp. 25-42, 2013.

[3] Azman, N., Halim, S.A., Liu, O.P., Saidin, S. \& Komoo, I., Public education in heritage conservation for geopark community. Procedia-Social and Behavioral Sciences, 7, pp. 504-511, 2010. https://doi.org/10.1016/j.sbspro.2010.10.068

[4] LADA. Geopark. 2014 November 24, from: http://www.lada.gov.my/v2/en/product/ geopark.html.

[5] ProGEO, Conserving our shared geoheritage - a protocol on geoconservation principles, sustainable site use, management, fieldwork, fossil and mineral collecting. 2011.

[6] Fauzi, N.S.M. \& Misni, A., Geoheritage conservation: indicators affecting the condition and sustainability of Geopark - a conceptual review. Procedia - Social and Behavioral Sciences, 222, pp. 676-684, 2016.

https://doi.org/10.1016/j.sbspro.2016.05.224

[7] Architectureyp. SWOT Analysis. 2016 November 2, available at http://architectureyp. blogspot.my/2007/05/swot-analysis.html.

[8] LADA and Kumpulan Governans Pemuliharaan Warisan dan Pendidikan Universiti Kebangsaan Malaysia (UKM), Pelan Pengurusan Langkawi Geopark 2012-2030: Pelan Tindakan, L.P.L. (LADA), Editor. 2012, Institut Alam Sekitar dan Pembangunan (LESTARI): Malaysia, pp. 1-128.

[9] Samsudin, M. \& Mohamad, S., Pengaruh warisan sejarah dalam industri pelancongan Langkawi. International Journal of the Malay World and Civilisation, 1(1), pp. 99-109, 2013.

[10] LADA. Langkawi UNESCO Global Geopark. 2016 November 8, available at https:// www.lada.gov.my/index.php/mengenai-kami/produk/langkawi-unesco-globalgeopark. 
[11] Augustin, R., Precious mangroves in Langkawi Geopark illegally destroyed, 2016 February 25, available at http://www.freemalaysiatoday.com/category/nation/2016/01/20/ precious-mangroves-in-langkawi-geopark-illegally-destroyed/.

[12] Idris, S.M.M., Mangrove forest in Kilim Geo Park under threat. Mangroves here are being threatened by tourist boat activities and pollution due to littering. 2016 November 17, available at http://www.freemalaysiatoday.com/category/opinion/2016/05/27/ mangrove-forest-in-kilim-geo-park-under-threat/.

[13] NAHRIM and NRE, The Study on Riverbank Erosion Due to Shipwake at Kilim Geoforest Park, Langkawi, (NRE), Editor. 2015, NAHRIM: Malaysia, pp. 1-41. 